\title{
POVEZANOST VRŠNJAČKOG NASILJA, OSOBINA LIČNOSTI I VASPITNIH STAVOVA
}

\section{Jelena Maksimović, Dušica Raković, Ivana Jovanović i Petar Čolović1}

Odsek za psihologiju, Filozofski fakultet, Novi Sad

Istraživanje je sprovedeno u cilju utvrđivanja latentne strukture fenomena vršnjačkog nasilja, operacionalizovanog upitnikom PRONA, kao i utvrđivanja povezanosti dimenzija vršnjačkog nasilja sa osobinama ličnosti Ajzenkovog PEN modela, vaspitnim stavovima roditelja, uzrastom i polom. Istraživanje je sprovedeno na uzorku od 123 ispitanika, oba pola, učenika V, VI $i$ VII razreda osnovne škole. Konstrukt vršnjačkog nasilja operacionalizovan je 42- ajtemskim upitnikom PRONA; za procenu osobina ličnosti PEN modela primenjen je 98- ajtemski upitnik Junior EPQ (JEPQ), dok su vaspitni stavovi roditelja procenjivani Upitnikom vaspitnih stavova (UVS), koji obuhvata 49 stavki. Analizom glavnih komponenti, u prostoru merenja upitnika PRONA ekstrahovane su tri glavne komponente dimenzije, koje zajedno objašnjavaju oko 31\% varijanse; komponente su postavljene u Promax poziciju. Promax dimenzije su interpretirane kao rizično ponašanje, viktimizacija i psihološko nasilje. Povezanost ovih dimenzija sa osobinama ličnosti, vaspitnim stavovima, uzrastom $i$ polom ispitana je multivarijatnom analizom kovarijanse. Faktorski skorovi na Promax dimenzijama iz prostora upitnika PRONA bili su kriterijske varijable, kategorijalni prediktor bio je pol, a skup kovarijeteta činili su uzrast i faktorski skorovi na prvim glavnim komponentama upitnika JEPQ i UVS. Sve kriterijske varijable ostvaruju značajnu povezanost sa prediktorskim skupom. Značajne parcijalne doprinose predikciji skora na dimenziji rizično ponašanje daju Psihoticizam, Neuroticizam i L skala; sa dimenzijom viktimizacija značajne parcijalne veze ostvaruju Neuroticizam, L skala i restriktivni vaspitni stavovi majke, dok su sa dimenzijom psihološko nasilje značajno povezani pol i Psihoticizam. Rezultati su generalno u skladu sa dosadašnjim nalazima o strukturi i korelatima vršnjačkog nasilja.

Ključne reči: vršnjačko nasilje, PEN model, vaspitni stavovi roditelja

\footnotetext{
${ }^{1}$ E-mail: p.etar@EUnet.rs
} 


\section{Uvod}

Budući da se, poslednjih decenija, na globalnom nivou zapaža tendencija porasta nasilja i agresivnog ponašanja u školama (Bullosk, 2002, prema Jankauskiene, Kardelis, Sukys, \& Kardeliene, 2008; Dake et al., 2003, prema Jankauskiene et al., 2008; Soen, 2002, prema Gašić-Pavičić, 2004), struktura i korelati vršnjačkog nasilja sve češće predstavljaju predmet psiholoških istraživanja. Sam termin vršnjačko nasilje, alias „buling“, tj. siledžijstvo, nasilništvo (od engleske reči „bully“) označava širok dijapazon manifestacija nasilnog ponašanja učenika. Okvirno, ono se može definisati kao skup agresivnih oblika ponašanja za koja je karakteristično ponavljanje i nejednak odnos snaga između nasilnika i žrtve (Olweys, 1999, prema Smith \& Brain, 2000).

Najrasprostranjeniji vid vršnjačkog nasilja je fizičko nasilje, koje podrazumeva zadavanje fizičke povrede ili neugodnosti drugome, udaranje rukama ili nogama, štipanje ili sputavanje telesnim dodirom (Gašić-Pavišić, 2004). Druga vrsta vršnjačkog nasilja u školi je psihološko nasilje koje se vrši verbalnim (ruganje, zadirkivanje, vređanje, pretnje) i neverbalnim napadom (nepristojni pokreti, grimase, namerno isključivanje nekoga iz društva i odbijanje da se udovolji željama drugoga) kao i namernom marginalizacijom i zapostavljanjem. Shodno tome, može se govoriti i o direktnim i indirektnim oblicima nasilnog ponašanja (Baldry, 2003), iz kojih proizilaze analogne forme viktimizacije - direktna i indirektna.

Iako su istraživanja povezanosti bazičnih dimenzija ličnosti i vršnjačkog nasilja malobrojna, slaba kontrola impulsivnog ponašanja pokazala se, pored same agresivnosti, kao značajan korelat nasilničkog ponašanja (Sinobad, 2005). Uz to, neki nalazi sugerišu da izvesni oblici rizičnog (pa i samodestruktivnog) ponašanja, poput konzumiranja cigareta i alkohola, korespondiraju sa nasilništvom (West \& Sweeting, 1997, prema Jankauskiene et al., 2008). Komplementarno tome, viktimizacija je najčešće povezana sa manjkom samopouzdanja i pasivnošću (Erling \& Hwang, 2004, prema Frisen, Jonsson, \& Persson, 2007; Bjorkqvist et al., 1982, prema Frisen et al., 2007), mada su, pored pasivnih žrtava, identifikovane i tzv. žrtve-provokatori (Olweys, 1998, prema Sinobad, 2005). Pasivne žrtve (Olweys, 1998 prema Sinobad, 2005) su brojnije i odlikuju se time što su oprezne, osetliive i tihe. Ova deca sebe opažaju kao neprivlačne, "promašene" i slabije od ostalih, čime i objašnjavaju svoju podložnost vršnjačkom nasilju (Bjorkqvist et al., 1982, prema Frisen et al., 2007; Erling \& Hwang, 2004, prema Frisen et al., 2007). Fizička slabost i nesigurnost, u kombinaciji sa uplašenošću, odaje utisak nesigurnih osoba koje neće uzvratiti ukoliko ih neko napadne; to može predstavljati i svojevrsnu provokaciju za nasilnike (Fox \& 
Boulton, 2005, prema Jankauskiene et al., 2008). Ipak, sam pojam „žrtveprovokatora" podrazumeva nešto drugačiji repertoar ponašanja. Naime, reč je o deci čije neinhibirano ponašanje provocira napade, na koje žrtve reaguju i strahom i agresijom (Olweys, 1999, prema Sinobad, 2005). Nalazi domaćih istraživanja (Plut i Popadić, 2007) sugerišu da se, u zavisnosti od njihovog odnosa prema nasilju, mogu razlikovati četiri grupe učenika: nasilnici, žrtve, žrtve i nasilnici istovremeno, i neuključeni. Ovakva klasifikacija u skladu je sa rezultatima ranijih studija (Salmivalli, Lagerspetz, Bjorkqvist, Osterman, \& Kaukiainen, 1996; Salmivalli, 1999, prema Plut i Popadić, 2007; Olweys et al., 1999, prema Plut i Popadić, 2007), i sugeriše da nasilničko ponašanje i ponašanje svojstveno žrtvi ne moraju nužno predstavljati suprotne polove kontinuuma.

Nalazi koji navode da su nasilnici „temperamentni“, da nasilje i agresiju smatraju sredstvima za postizanje moći i uticaja među vršnjacima i da su odrasli u neadekvatnom porodičnom okruženju (Olweys, 1999, prema Frisen et. al., 2007) upućuju na porodičnu klimu kao važnu determinantu nastanka i razvoja nasilničkog ponašanja. Rigbi (Rigby, 1996, prema Baldry, 2003) smatra da slaba roditeljska briga za decu i neobraćanje pažnje na njihova osećanja mogu biti značajni faktori za nastanak bulinga. Sinobad (Sinobad, 2005) navodi da su faktori koji dovode do razvoja bulinga preterana popustljivost roditelja i dopuštanje nasilničkog ponašanja, nedostatak topline i pažnje, fizičko kažnjavanje i burno reagovanje roditelja.

Polne razlike prisutne su kako u načinu manifestovanja nasilničkog ponašanja, tako i u izloženosti određenim vidovima nasilja. Studije pokazuju da su dečaci skloniji (ali i izloženiji) fizičkom nasilju, dok su devojčice češće žrtve psihološkog nasilja, kome u većoj meri i pribegavaju (Björkqvist, Lagerspetz, \& Kaukiainen, 1992; Österman et al., 1998; Olweys, 1998, prema Sinobad, 2005). Razlike u manifestovanju nasilničkog ponašanja po svoj prilici su pod znatnim uticajem polnih stereotipa: očekuje se da dečaci budu jaki i otvoreno agresivni, dok je agresivnost devojčica zabranjena, pa se one opredeljuju za skrivenije strategije nasilnog ponašanja (Österman et al., 1998). Rezultati koji beleže trend opadanja bulinga od 8. do 16. godine starosti (Smith et al., 1999, prema Frisen et al., 2007), ukazuju na potencijalno značajnu vezu uzrasta i vršnjačkog nasilja, ali ne pružaju informacije o strukturi i prirodi te veze. Stavovi dece o vršnjačkom nasilju takođe ukazuju da uzrast može biti važan faktor formiranja i ispoljavanja nasilničkog ponašanja. Na pitanje zašto buling, po njihovom mišljenju, prestaje, deca su uglavnom odgovarala da je to zato što nasilnik sazreva. Žrtve su, u većoj meri nego nasilnici, odgovarale da je nasilje prestalo kada su oni prestali da se drastično razlikuju od svojih vršnjaka (Oliver et 
al., 1994, prema Frisen et al., 2007). Neke studije (donekle u suprotnosti sa nalazima o uzrasnom trendu opadanja vršnjačkog nasilja) pokazuju da je saosećanje sa žrtvom intenzivnije kod mlađe dece, ali da se smanjuje do 15 godine učenika, kada se opet povećava (Menesini et al., 1997, prema Smith, 1997; Rigbz \& Slee, 1991, prema Smith, 1997).

Smatra se da različiti oblici nasilja mogu imati ozbiljne posledice po mentalno i fizičko zdravlje žrtve (Brain, 1997, prema Smith \& Brain, 2000); zabeleženi su slučajevi žrtava koje su, usled kontinuiranog zlostavljanja, izvršile samoubistvo. Pored negativnih posledica koje nasilje ima na žrtvu, važno je razmotriti i kako nasilništvo utiče na dobrobit nasilnika (fizički, psihički i socijalno). Vršnjačko nasilje je u vezi sa nižim akademskim postignućem, kršenjem školskih pravila i varanjem na ispitima (Dake et al., 2003, prema Jankauskiene et al., 2005; Glew et al. 2005, prema Jankauskiene et al., 2008). Sve ovo upućuje na neophodnost razvoja programa prevencije nasilništva. U razvijenim zemljama se na vršnjačko nasilje gleda kao na nacionalni problem za čije je rešavanje potreban zajednički rad više sektora. Antibuling programi najbolji su ukoliko u radu uključuju i učenike i školsko osoblje, počinju u predškolskim ustanovama i odnose se na ceo vaspitno-obrazovni program. U skladu s tim, svaka škola bi trebalo da odabere preventivni program primeren potrebama (GašićPavišić, 2004).

Evidentno je da je vršnjačko nasilje složen konstrukt, sa različitim modalitetima ispoljavanja čiji odnosi nisu u potpunosti razjašnjeni. Između ostalog, rezultati koji donekle protivreče intuitivnim očekivanjima vezanim za odnos nasilničkog ponašanja i ponašanja žrtve (sugerišući da ovi fenomeni ne moraju biti negativno linearno povezani) ukazuju na potrebu da se latentna struktura fenomena vršnjačkog nasilja podrobnije ispita. Složenost samog konstrukta odražava se i na njegove relacije sa drugim fenomenima; ilustracija za to mogu biti rezultati domaćih istraživanja (Jugović, 2004; Stojadinović, 2004, prema Mitrović, Smederevac, Grujičić i Čolović, 2006), koji sugerišu da osobine ličnosti i porodica mogu biti faktori rizika za pojavu nasilnog ponašanja dece, a s druge strane mogu predstavljati i protektivne faktore koji sprečavaju razvijanje i ispoljavanje ovih oblika ponašanja. Relacije pola i uzrasta sa vršnjačkim nasiljem takođe nisu u potpunosti rasvetljene; to se prevashodno odnosi na uzrast, budući da postoji vrlo malo (donekle kontradiktornih) podataka o efektima sazrevanja na manifestovanje vršnjačkog nasilja. S obzirom na kompleksnost fenomena vršnjačkog nasilja i njegove brojne korelate, ovo istraživanje je s jedne strane usmereno na utvrđivanje latentne strukture skupa indikatora nasilničkog (i srodnih) ponašanja, a s druge na utvrđivanje povezanosti dimenzija vršnjačkog nasilja sa relevantnim konstruktima- osobinama 
ličnosti, vaspitnim stavovima roditelja, polom i uzrastom. Može se, naime, očekivati da će izraženija sklonost ka nasilničkom ponašanju korespondirati sa izraženijom agresivnošću, impulsivnošću i sklonošću ka rizičnim ponašanjima, te da su ovakve tendencije u vezi sa manje povoljnom porodičnom klimom. Takođe, okvirno se može očekivati da će dečaci ispoljiti izraženiju sklonost ka manifestnim oblicima vršnjačkog nasilja.

\section{Metod}

\section{Uzorak}

Istraživanje je sprovedeno tokom maja 2008, na uzorku od 123 ispitanika, oba pola (59 dečaka i 64 devojčice), starosti 11 - 13 godina. Ispitanici su bili učenici V, VI i VII razreda Osnovne škole „Žarko Zrenjanin“ u Novom Sadu. Upitnici su administrirani ispitanicima tokom redovne nastave, uz prisustvo ispitivača (apsolvenata psihologije) i nastavnika. Pre samog ispitivanja, ispitanicima je pročitano i protumačeno uputstvo za popunjavanje upitnika.

\section{Instrumenti}

Primenjeni su sledeći instrumenti:

1. Upitnik za procenu vršnjačkog nasilja (PRONA; Maksimović i sar., 2008). Upitnikom PRONA, konstruisanim za potrebe ovog istraživanja, obuhvaćen je širok spektar indikatora vršnjačkog nasilja. U upitnik su uključeni markeri sklonosti ka fizičkoj agresiji (što podrazumeva kako neposredno učešće u fizičkim napadima na drugu decu, tako i podsticanje fizičkog nasilja), psihološkog nasilja (poput pretnji, ogovaranja, ismevanja, ignorisanja, iznuđivanja usluga, i sl.), do trpljenja različitih formi agresije. Pored bihejvioralnih manifestacija vršnjačkog nasilja u užem smislu, upitnikom su obuhvaćeni i markeri nekih rizičnih ponašanja koja se mogu smatrati korelatima nasilništva (eksperimentisanje psihoaktivnim supstancama, učestvovanje u sitnim krađama, itd.). Instrument sadrži 42 stavke sa Likertovim formatom odgovora, od kojih su 7 fileri.

2. Ajzenkov upitnik ličnosti- verzija za decu (Junior Eysenck Personality Questionnaire- JEPQ; Eysenck \& Eysenck, 1975, prema Fonseca \& Yule, 1995). U cilju procene osobina ličnosti PEN modela, primenjena je 98- ajtemska verzija upitnika JEPQ (Eysenck \& Eysenck, 1975 prema Fonseca \& Yule, 1995; Barrett, 1999), koju je na srpski jezik preveo Pero Šipka. Donja starosna granica za primenu instrumenta je 11 godina (Kline, 2000). Upitnik obuhvata 
skale Psihoticizma (34 stavke), Neuroticizma (20 stavki), Ekstraverzije (24 stavke) i skalu socijalne poželjnosti (L) (20 stavki). Svi ajtemi podrazumevaju binarni format odgovora.

3. Upitnik vaspitnih stavova (UVS; Genc i Kodžopeljić, 1995) namenjen je dečijoj proceni vaspitnih stavova roditelja. Upitnikom su obuhvaćene dve bipolarne dimenzije vaspitnih stavova. Ekstremi afektivne dimenzije mogu se definisati kao toplo nasuprot hladnom vaspitanju, dok se u okviru dimenzije kontrole nalaze indikatori popustljivog nasuprot ograničavajućeg vaspitanja. U izvornoj verziji upitnika, svaka skala obuhvata 22 stavke, pri čemu se vaspitni stavovi oca i majke procenjuju odvojeno. Za potrebe ovog istraživanja, skali za procenu afektivne dimenzije vaspitanja dodato je 5 stavki koje se odnose na različite vidove zlostavljanja ili zanemarivanja dece u porodici.

Tabela 1 Pokazatelji reprezentativnosti, pouzdanosti i homogenosti skala upitnika JEPQ i UVS

\begin{tabular}{lccccc}
\hline & $\mathrm{MSA}^{1}$ & $\mathrm{a}^{2}$ & $\beta^{3}$ & $\mathrm{H}^{4}$ & $\mathrm{H}^{5}$ \\
\hline Psihoticizam & .65 & .81 & .84 & .11 & .29 \\
Neuroticizam & .76 & .81 & .83 & .18 & .52 \\
L skala & .78 & .81 & .83 & .17 & .58 \\
Ekstraverzija & .63 & .75 & .77 & .11 & .36 \\
Vaspitna dimenzija kontrole - otac & .68 & .69 & .77 & .90 & .34 \\
Afektivna dimenzija vaspitanja - otac (27 & & & & & \\
stavki)* & .85 & .92 & .93 & .31 & .58 \\
Vaspitna dimenzija kontrole - majka & .69 & .70 & .78 & .10 & .37 \\
Afektivna dimenzija vaspitanja - majka & & & & & \\
(27 stavki) & .80 & .90 & .91 & .24 & .48 \\
\hline
\end{tabular}

${ }^{1}$ normalizovani Kajzer - Majer - Olkinov koeficijent reprezentativnosti; ${ }^{2}$ Cronbach - koeficijent pouzdanosti (tip interne konzistencije); ${ }^{3}$ Lord - Kaiser - Caffrey- koeficijent pouzdanosti prve glavne komponente; ${ }^{4}$ prosečna interkorelacija stavki; ${ }^{5}$ Momirović - relativna veličina varijanse prve glavne imaž komponente

"Metrijske karakteristike 22- ajtemskih skala afektivnih dimenzija vaspitanja: afektivna dimenzija vaspitanja - otac: $\mathrm{MSA}=.85, \alpha=.90, \beta=.91, \mathrm{H} 1=.28, \mathrm{H} 2=.60$; afektivna dimenzija vaspitanja - majka: $\mathrm{MSA}=.76, \alpha=.85, \beta=.86, \mathrm{H} 1=.20, \mathrm{H} 2=.45$

Metrijske karakteristike skala upitnika JEPQ i UVS (Tabela 1) generalno su prihvatljive. Nešto slabijim metrijskim svojstvima izdvajaju se skala Ekstraverzije upitnika JEPQ i skale vaspitnih dimenzija kontrole upitnika UVS. Dopuna skala afektivnih dimenzija vaspitanja u izvesnoj meri je poboljšala njihove metrijske karakteristike. Opterećenja novih stavki prvim glavnim komponentama kreću se u rasponu 0,28 - 0,6 za afektivnu dimenziju vaspitanja oca, i u rasponu 0,63 - 0,76 za afektivnu dimenziju vaspitanja majke. 
Odgovori na stavkama upitnika JEPQ i UVS sažeti su na prve glavne komponente supskala; faktorski skorovi na prvim glavnim komponentama korišćeni su u daljim analizama. Dimenzije vršnjačkog nasilja definisane su kao faktorski skorovi na Promax glavnim komponentama ekstrahovanim u prostoru merenja upitnika PRONA. Prikupljani su i podaci o polu i uzrastu (11 - 13 godina).

\section{Rezultati}

\section{Latentna struktura prostora merenja upitnika PRONA}

Latentna struktura skupa indikatora vršnjačkog nasilja, obuhvaćenih upitnikom PRONA, ispitana je analizom glavnih komponenti. Iz analize su isključene stavke - fileri, te je početni skup varijabli obuhvatio odgovore na 35 ajtema upitnika PRONA. Prema Scree kriterijumu, u analizi su zadržane tri glavne komponente koje zajedno objašnjavaju 30.76 \% varijanse sistema varijabli (Tabela 2). Zadržane komponente postavljene su u Promax poziciju.

Tabela 2 Karakteristični koreni i procenat objašnjene varijanse

\begin{tabular}{ccccc}
\hline & \multicolumn{3}{c}{ Pre rotacije } & Nakon rotacije \\
\cline { 2 - 5 } $\begin{array}{c}\text { kompo- } \\
\text { nente }\end{array}$ & $\begin{array}{c}\text { Karakteristični } \\
\text { koren }\end{array}$ & $\begin{array}{c}\text { Procenat } \\
\text { varijanse }\end{array}$ & $\begin{array}{c}\text { Kumulativni } \\
\text { procenat }\end{array}$ & $\begin{array}{c}\text { Karakteristični } \\
\text { koren }\end{array}$ \\
\hline 1. & 4.98 & 14.22 & 14.22 & 4.30 \\
2. & 3.78 & 10.78 & 25.00 & 3.75 \\
3. & 2.01 & 5.75 & 30.76 & 3.79 \\
\hline
\end{tabular}




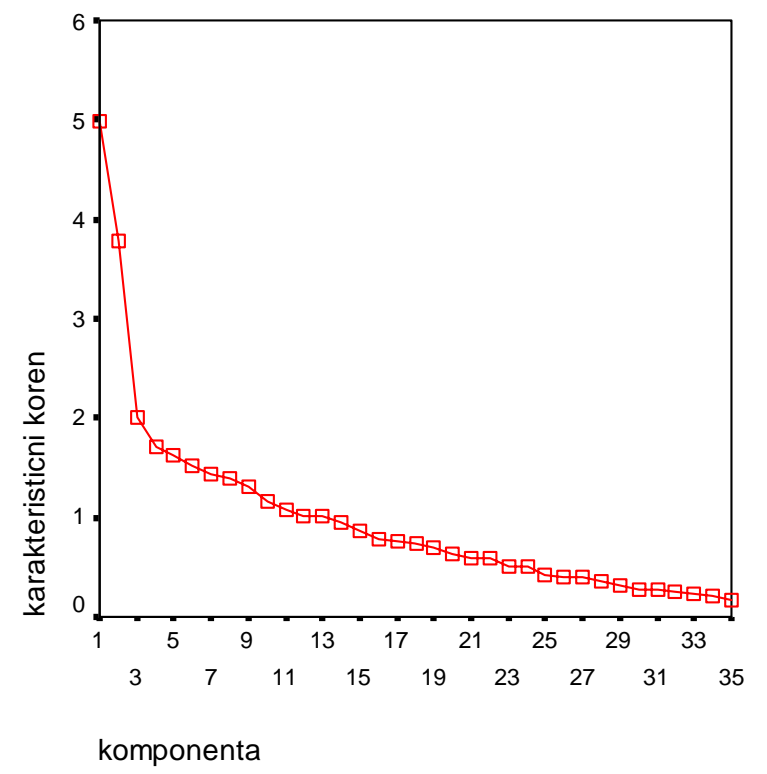

Grafik 1. Scree dijagram

Prvu Promax komponentu (Tabela 3) određuju ajtemi koji se odnose na različite oblike socijalno neprihvatljivog ponašanja poput konzumiranja alkohola, cigareta i marihuane, kao i učestvovanja u krađi; sklopu i strukturi ove dimenzije značajno doprinose i indikatori slabijeg uspeha u školi. Prva Promax dimenzija obuhvata i ajteme koji se odnose na sklonost ka tuči, fizičkom obračunavanju i svađi, kao i na nameru da se druga deca fizički povrede i osramote. Dakle, ova dimenzija se odnosi na različite oblike neprihvatljivog ponašanja, što podrazumeva i agresiju usmerenu ka drugima (odnosno direktno, otvoreno fizičko nasilje prema vršnjacima), pa se može imenovati kao rizično ponašanje. 
Tabela 3 Izvod iz matrica sklopa i strukture prve Promax komponente

\begin{tabular}{lccl}
\hline Stavke & sklop & struktura & $\mathrm{h}^{2}$ \\
\hline 30. Probao sam cigarete. & .81 & .71 & .57 \\
26. Ponekad s drugovima pijem alko- & & & .44 \\
holna pića. & .69 & .63 & \\
5. Često se svađam sa drugom decom. & .56 & .54 & .29 \\
10. Dešavalo se da nešto ukradem. & .50 & .49 & .28 \\
35. Tukao sam se sa drugovima u školi. & .48 & .54 & .34 \\
11. Dobar sam đak. & -.45 & -.37 & .23 \\
36. Umem da "zakuvam" tuču. & .43 & .57 & .51 \\
42. Zadirkujem drugove zbog nekog & & & .27 \\
njihovog nedostatka ili mane. & .42 & .49 & \\
15. Volim da izblamiram pred svima & & & .21 \\
one koji me nerviraju. & .41 & .44 & \\
27. Potukao sam se da bih odbranio & & & .22 \\
druga. & .39 & .45 & \\
31. Probao sam marihuanu. & .37 & .22 & .20 \\
33. Redovno gledam američko rvanje. & .34 & .37 & .15 \\
23. Nikada ne bih povredio drugu decu. & -.34 & -.37 & .15 \\
38. Volim da čitam. & -.33 & -.38 & .19 \\
\hline
\end{tabular}

$\mathrm{h}^{2}$ - komunalitet nakon ekstrakcije

Druga Promax komponenta (Tabela 4) određena je ajtemima čiji se sadržaj odnosi na situacije u kojima dete trpi direktnu fizičku ili verbalnu agresiju (zadirkivanja, ućutkivanja i sl.). Ovom dimenzijom obuhvaćeni su i ajtemi koji ukazuju da je dete žrtva psihološkog nasilja - izbegavanja, sramoćenja, ruganja i pretnje od strane svojih vršnjaka. Ova Promax komponenta može se definisati kao viktimizacija. 
Tabela 4 Izvod iz matrica sklopa i strukture druge Promax komponente

\begin{tabular}{lccc}
\hline Stavke & sklop & struktura & $\mathrm{h}^{2}$ \\
\hline 12. Dobio sam batine od druge dece u školi. & .70 & .65 & .54 \\
6. Deca me često zadirkuju. & .65 & .62 & .44 \\
7. Deca mi se često rugaju. & .63 & .63 & .40 \\
19. Jača deca me često guraju. & .63 & .60 & .40 \\
3. Često me druga deca ućutkuju kada poku- & .59 & .58 & .38 \\
šam nešto da kažem. & .58 & .48 & .34 \\
20. Mnoga deca me izbegavaju. & .49 & .45 & .24 \\
$\begin{array}{l}\text { 13. Druga deca me prisiljavaju da im činim } \\
\text { sitne usluge. }\end{array}$ & & & \\
21. Neka deca me često izblamiraju pred & .46 & .38 & .21 \\
društvom. & & & \\
18. Izbegavam decu koja mi se ne sviđaju & .40 & .38 & .21 \\
zbog nekog nedostatka ili mane. & .38 & -.38 & .19 \\
22. Neka deca su mi pretila. & -.37 & & .16 \\
2. Branim drugove kada ih drugi zadirkuju. & &
\end{tabular}

$\mathrm{h}^{2}$ - komunalitet nakon ekstrakcije

Sa trećom Promax dimenzijom (Tabela 5) u najvećoj meri su povezani ajtemi koji se odnose na suptilnije i prikrivenije oblike nasilnog ponašanja učenika. Reč je o stavkama koje ukazuju na iznuđivanje usluga od druge dece, pretnje, isključivanje iz grupe i ogovaranje. Dimenzijom su obuhvaćeni i izvesni oblici manje intenzivnog fizičkog nasilja, čija svrha nije nanošenje povreda, već ismevanje ili ponižavanje žrtve. Dimenzija je imenovana kao psihološko nasilje. 
Tabela 5 Izvod iz matrica sklopa i strukture treće Promax komponente

\begin{tabular}{|c|c|c|c|}
\hline Stavke & sklop & $\begin{array}{c}\text { struk- } \\
\text { tura }\end{array}$ & $h^{2}$ \\
\hline 14. Druga deca moraju da mi čine sitne usluge. & .78 & .77 & .60 \\
\hline $\begin{array}{l}\text { 4. Često mlađu decu u prolazu čvrgnem, udarim ili } \\
\text { počupam. }\end{array}$ & .77 & .75 & .56 \\
\hline $\begin{array}{l}\text { 37. Uspevam da ubedim društvo da se ne družimo sa } \\
\text { onima koji nam se ne dopadaju. }\end{array}$ & .50 & .48 & .27 \\
\hline $\begin{array}{l}\text { 8. Dešavalo mi se da ponesem u školu nožić ili neko } \\
\text { drugo sredstvo za odbranu. }\end{array}$ & .42 & .48 & .25 \\
\hline 31. Probao sam marihuanu. & -.41 & -.28 & .20 \\
\hline 25. Ogovaram sa društvom one koji to zasluže. & .40 & .40 & .16 \\
\hline 40. Volim filmove u kojima ima puno nasilja. & .40 & .53 & .40 \\
\hline 28. Pretio sam onima koji me nerviraju. & .40 & .49 & .39 \\
\hline $\begin{array}{l}\text { 24. Obično se guram na odmoru sa decom slabijom } \\
\text { od sebe. }\end{array}$ & .35 & .36 & .13 \\
\hline $\begin{array}{l}\text { 9. Dešavalo mi se da prvi namerno udarim druga u } \\
\text { školi. }\end{array}$ & .33 & .42 & .35 \\
\hline 36. Umem da "zakuvam" tuču. & .42 & .58 & .51 \\
\hline
\end{tabular}

$\mathrm{h}^{2}$ - komunalitet nakon ekstrakcije

Najviši koeficijent korelacije $(\mathrm{r}=0,358)$, ostvaruju dimenzije rizično ponašanje i psihološko nasilje. Preostali koeficijenti korelacije su zanemarljive visine; koeficijent korelacije između dimenzija rizično ponašanje i viktimizacija iznosi -0,083, a između varijabli viktimizacija i psihološko nasilje -0,026. Skale upitnika PRONA, formirane na osnovu matrice sklopa Promax dimenzija, imaju prihvatljivu pouzdanost, reprezentativnost i homogenost (Tabela 6). Nijedna skala metrijskim kvalitetom ne odstupa znatno od ostalih.

Tabela 6 Pokazatelji reprezentativnosti, pouzdanosti i homogenosti skala upitnika PRONA

\begin{tabular}{lccccc}
\hline & $\mathrm{MSA}^{1}$ & $\mathrm{a}^{2}$ & $\beta^{3}$ & $\mathrm{H} 1^{4}$ & $\mathrm{H} 2^{5}$ \\
\hline Rizično ponašanje & .73 & .75 & .76 & .19 & .62 \\
Viktimizacija & .74 & .77 & .78 & .23 & .68 \\
Psihološko nasilje & .74 & .71 & .74 & .19 & .70 \\
\hline
\end{tabular}

${ }^{1}$ normalizovani Kajzer - Majer - Olkinov koeficijent reprezentativnosti; ${ }^{2}$ Cronbach - koeficijent pouzdanosti (tip interne konzistencije); ${ }^{3}$ Lord - Kaiser - Caffrey- koeficijent pouzdanosti prve glavne komponente; ${ }^{4}$ prosečna interkorelacija stavki; ${ }^{5}$ Momirović - relativna veličina varijanse prve glavne imaž komponente 
Relacije između dimenzija vršnjačkog nasilja i osobina ličnosti, pola, uzrasta i vaspitnih stavova

Povezanost pola, uzrasta, osobina ličnosti, vaspitnih stavova i dimenzija vršnjačkog nasilja ispitana je multivarijatnom analizom kovarijanse. Kategorijalni prediktor u analizi bio je pol; skup kontinuiranih prediktora (kovarijeteta) činili su uzrast, faktorski skorovi na prvim glavnim komponentama skala upitnika JEPQ i faktorski skorovi na prvim glavnim komponentama skala upitnika VS, dok su kriterijske varijable bili faktorski skorovi na Promax glavnim komponentama iz prostora merenja upitnika PRONA.

Tabela 7 Multivarijatni efekti prediktora

\begin{tabular}{lccccc}
\hline & $\begin{array}{c}\text { Vilksova } \\
\text { lambda }\end{array}$ & F & Df (efekat) & Df (greška) & $\mathrm{p}$ \\
\hline Intercept & .98 & .67 & 3 & 110 & .57 \\
Uzrast & .98 & .65 & 3 & 110 & .59 \\
Psihoticizam & .80 & 9.11 & 3 & 110 & .00 \\
Neuroticizam & .89 & 4.52 & 3 & 110 & .01 \\
L skala & .87 & 5.28 & 3 & 110 & .00 \\
$\begin{array}{l}\text { Ekstraverzija } \\
\text { Vaspitna dimenzija kontrole - }\end{array}$ & .84 & 6.94 & 3 & 110 & .00 \\
otac & .97 & 1.27 & 3 & 110 & .29 \\
Afektivna dimenzija vaspitanja & & & & & \\
- otac & .97 & 1.15 & 3 & 110 & .33 \\
Vaspitna dimenzija kontrole - & & & & & \\
majka & .95 & 1.87 & 3 & 110 & .14 \\
Afektivna dimenzija vaspitanja & & & & & \\
- majka & .94 & 2.35 & 3 & 110 & .08 \\
Pol & .88 & 5.08 & 3 & 110 & .00 \\
\hline
\end{tabular}

Značajne multivarijatne efekte (Tabela 7) ostvaruju sve prediktorske varijable, izuzev uzrasta. Značajne univarijatne efekte za kriterijsku varijablu rizično ponašanje imaju Psihoticizam $(\mathrm{F}(1,112)=19, \mathrm{p}<0,001)$, Ekstraverzija $(\mathrm{F}(1,112)=16,31, \mathrm{p}<0,001)$ i L skala $(\mathrm{F}(1,112)=5,54, \mathrm{p}<0,05)$. Značajne univarijatne efekte za kriterijum viktimizacija ostvaruju Neuroticizam $(\mathrm{F}(1,112)=$ 7,89, $\mathrm{p}<0,01)$, L skala $(\mathrm{F}(1,112)=7,42, \mathrm{p}<0,01)$, i afektivna dimenzija vaspitanja majke $(\mathrm{F}(1,112)=5,35, \mathrm{p}<0,05)$. Za kriterijsku varijablu psihološko nasilje, značajne efekte imaju pol $(\mathrm{F}(1,112)=9,87, \mathrm{p}<0,01)$ i Psihoticizam $(\mathrm{F}(1,112)=7,90$, $\mathrm{df}=1, \mathrm{p}<0,01)$. 
Tabela 8 Koeficijenti multiple korelacije i parcijalni doprinosi prediktora

\begin{tabular}{|c|c|c|c|c|c|c|}
\hline & \multicolumn{2}{|c|}{$\begin{array}{c}\text { Rizično ponašanje } \\
R=.735 ; \mathrm{p}<.001\end{array}$} & \multicolumn{2}{|c|}{$\begin{array}{l}\text { Viktimizacija } \\
\mathrm{R}=.55 ; \mathrm{p}<.001\end{array}$} & \multicolumn{2}{|c|}{$\begin{array}{c}\text { Psihološko nasilje } \\
\mathrm{R}=.544 ; \mathrm{p}<.001\end{array}$} \\
\hline & B & $\mathrm{p}$ & B & $p$ & $\beta$ & $p$ \\
\hline Intercept & & .19 & & .67 & & .78 \\
\hline Uzrast & .09 & .19 & -.04 & .67 & .02 & .79 \\
\hline Psihoticizam & .37 & .00 & .15 & .15 & .30 & .01 \\
\hline Neuroticizam & -.14 & .06 & .24 & .01 & -.13 & .13 \\
\hline L skala & -.19 & .02 & .27 & .01 & -.18 & .07 \\
\hline Ekstraverzija & .29 & .00 & -.17 & .06 & .10 & .27 \\
\hline Vaspitna dimenzija kontrole & & & & & & \\
\hline- otac $^{*}$ & .06 & .64 & -.13 & .42 & -.27 & .10 \\
\hline $\begin{array}{l}\text { Afektivna dimenzija vaspi- } \\
\text { tanja - otac }\end{array}$ & -.08 & .45 & .22 & .10 & -.03 & .82 \\
\hline $\begin{array}{l}\text { Vaspitna dimenzija kontrole } \\
\text { - majka }\end{array}$ & -.02 & .89 & .41 & .02 & .09 & .62 \\
\hline $\begin{array}{l}\text { Afektivna dimenzija vaspi- } \\
\text { tanja - majka }\end{array}$ & .25 & .06 & -.29 & .08 & -.04 & .79 \\
\hline Pol (muški spram ženskog) & .12 & .11 & .16 & .07 & .28 & .00 \\
\hline
\end{tabular}

*na pozitivnom polu vaspitnih dimenzija kontrole nalaze se indikatori restriktivnog vaspitanja, a na pozitivnom polu afektivnih dimenzija indikatori hladnog vaspitnog stava

Kriterijska varijabla rizično ponašanje sa skupom prediktora deli oko $54 \%$ varijanse. Predikciji ove varijable značajno doprinose tri prediktorske varijablePsihoticizam i Ekstraverzija sa pozitivnim, i L skala sa negativnim predznakom. Značajne parcijalne veze sa dimenzijom viktimizacija (koja sa skupom prediktora deli 30,2 \% varijanse), sve sa pozitivnim predznakom, ostvaruju Neuroticizam, L skala i procena restriktivnosti, odnosno permisivnosti vaspitnih stavova majke (viša izraženost restriktivnih vaspitnih stavova korespondira sa višim skorom na kriterijskoj varijabli). Značajne parcijalne doprinose predikciji skora na kriterijskoj varijabli psihološko nasilje (prediktorski skup objašnjava 29,6 \% njene varijanse) daju Psihoticizam, sa pozitivnim predznakom, i pol (dečaci postižu značajno više skorove od devojčica).

\section{Diskusija}

Rezultati ovog istraživanja sugerišu da latentni prostor upitnika PRONA čine tri latentne dimenzije. Prva, imenovana kao rizično ponašanje, odnosi se na različite oblike neprihvatljivog ponašanja, koji obuhvataju i agresiju usmerenu ka sebi ili ka drugima. Sadržaj ove dimenzije, koja objedinjuje rizična (pa i delinkventna) ponašanja i sklonost ka nasilništvu ide u prilog nalazima nekih 
ranijih studija (Dake et. al., 2003; West \& Sweeting, 1997, prema Jankauskiene et al., 2008; Glew et al., 2005 prema Jankauskiene et al., 2008). Međutim, priroda veze između ovih fenomena još uvek nije sasvim jasna; iako rezultati sugerišu da oni čine jedinstvenu latentnu dimenziju, ima i mišljenja da povezanost nije neposredna. Naime, neki autori smatraju da rizična ponašanja zapravo utiču na porast samopoštovanja i popularnosti, što olakšava ispoljavanje agresije (West \& Sweeting, 1997, prema Jankauskiene et al., 2008). Na temelju rezultata ovog istraživanja, ta interpretacija ne može se bezrezervno prihvatiti, ali ni u potpunosti odbaciti.

Druga izolovana Promax komponenta, imenovana kao viktimizacija, sadrži pretežno indikatore pasivnog ponašanja u ulozi žrtve, pri čemu su obuhvaćeni indikatori kako fizičkog, tako i psihološkog nasilja. U sadržaju ove dimenzije, primetna je izbegavajuća strategija ponašanja, i izvestan otklon prema socijalnom okruženju (žrtva izbegava one koji joj se ne sviđaju, i ne zauzima se za druge).

Naposletku, dimenzija interpretirana kao psihološko nasilje generalno se odnosi na oblike nasilnog ponašanja učenika koji ne uključuju intenzivnu fizičku agresiju, već su usmereni pre svega na zastrašivanje i ponižavanje žrtve, kao i na njeno izopštavanje iz grupnih aktivnosti. Neki oblici rizičnog ponašanja (konzumiranje marihuane) negativno su povezani sa ovom dimenzijom, ali izvesne podudarnosti sa prvom Promax komponentom ipak postoje, i ogledaju se pre svega u tendenciji ka podsticanju nasilja.

Nalazi o strukturi latentnog prostora upitnika PRONA uglavnom su saglasni sa opšteprihvaćenim stavovima o strukturi fenomena vršnjačkog nasilja. Međutim, indikatori fizičke agresije nisu formirali homogenu latentnu dimenziju; umesto toga, stavke koje se odnose na grublju fizičku agresiju (kako napadačku, tako i - barem deklarativno - zaštitničku) našle su se na prvoj, a opisi fizičkog nasilja slabijeg intenziteta primarno na trećoj latentnoj dimenziji. Dimenzija viktimizacija ne korelira znatno ni sa jednim od preostalih faktora, što ide u prilog tezi o mogućnosti preklapanja uloga nasilnika i žrtve. Generalno, može se reći da je vršnjačko nasilje kompleksan fenomen koji, očigledno, ima primarno fizički i primarno psihološki modalitet; pri tome, indikatori antisocijalnog ponašanja koje se može ispoljiti i na drugom planu korespondiraju pre svega sa fizičkom agresijom, što može uputiti na dalja istraživanja veze ovih fenomena sa bazičnim dimenzijama agresivnosti i kontrole impulsa.

Rezultati ispitivanja povezanosti između vršnjačkog nasilja, dimenzija ličnosti, vaspitnih stavova i pola ukazuju da su sve dimenzije iz prostora upitnika PRONA značajno povezane sa prediktorskim skupom. Jedino varijabla uzrast 
ne ostvaruje značajnu parcijalnu vezu ni sa jednim od kriterijuma. Moguće je da bi se, proširenjem raspona uzrasta, npr. na interval do 16 godina (što bi, shodno sugestijama nekih prethodnih studija, bilo primereno; Smith et al., 1999, prema Frisen et al., 2007), rezultati izmenili. Takođe, čini se da, pri ispitivanju veze uzrasta i dimenzija vršnjačkog nasilja, postoje izvesna metodološka ograničenja; reč je pre svega o neprikladnosti upitničkog ispitivanja i postupka samoprocene za mlađe uzraste, što njihovo uključivanje u istraživanja čini problematičnim. Moguće je i da povezanost uzrasta i dimenzija vršnjačkog nasilja nije linearna, ili da među uzrasnim grupama potencijalno postoje kvalitativne razlike.

Povezanost fizičkog nasilja sa prediktorskim skupom je najintenzivnija. Veza ove dimenzije sa Psihoticizmom i Ekstraverzijom po svoj prilici ukazuje na značajnu ulogu koju impulsivnost, agresivnost i sklonost ka traženju senzacija imaju u formiranju i razvoju rizičnih i nasilnih ponašanja. Negativna veza koju L skala ostvaruje sa dimenzijom rizično ponašanje naglašava antisocijalnu prirodu markera ove dimenzije; po svoj prilici, kombinacija visokih skorova na Psihoticizmu i Ekstraverziji i niskog na L skali ukazuje na slabu kontrolu impulsa, koja, uz agresivnost i sklonost ka traženju stimulacije u socijalnom okruženju, može dovesti do problematičnog ponašanja koje podrazumeva i nasilje prema drugima. Rezultati idu u prilog teze o temperamentalnoj podlozi nasilnog ponašanja (Olweys, 1999, prema Frisen et. al., 2007).

Kada je u pitanju viktimizacija, kao najbolji prediktor pokazao se skor na vaspitnoj dimenziji kontrole. Ujedno, ovo je jedina kriterijska varijabla koja je značajno parcijalno povezana sa nekom od dimenzija vaspitnih stavova. Procena vaspitnog stava majke kao rigidnijeg korespondira sa višim skorovima na dimenziji viktimizacija. Imajući u vidu da su i skorovi na Neuroticizmu i L skali značajno (u pozitivnom smeru) povezani sa skorom na dimenziji viktimizacija, moglo bi se zaključiti da inhibiranost, nekonfliktnost i hipersocijalizovanost koje proističu iz stroge roditeljske kontrole, uz visoku anksioznost i sklonost ka socijalnom povlačenju, predstavljaju predisponirajuće faktore za preuzimanje uloge pasivne žrtve nasilja.

Promax dimenzija imenovana kao psihološko nasilje ostvaruje značajne parcijalne veze sa polom i skorom na Psihoticizmu. Pokazalo se da su dečaci skloniji suptilnijim, prikrivenijim oblicima nasilja, što je prema rezultatima drugih studija (Österman et al., 1998; Björkqvist et al., 1992) specifičnije za devojčice. Visok doprinos Psihoticizma ukazuje na sklonost ka izopštavanju vršnjaka iz zajedničkih aktivnosti, ogovaranju, nepoštovanju pravila, te na nesklonost osećanju krivice i empatiji prema žrtvama, što je u skladu sa ranijim nalazima. Prisutnost koristoljubive komponente ponašanja kroz primoravanja na vrše- 
nje usluga, rezultat je koji je očekivan (Olweus, 1998, prema Sinobad, 2005). Imajući u vidu visok skor na Psihoticizmu kao prediktor skora na dimenziji psihološko nasilje, može se reći da postoje izvesne indicije koje govore u prilog pretpostavke (Kaukiainen, 1999, prema Smith \& Brain, 2000), o korišćenju visoke socijalne inteligencije $\mathrm{u}$ antisocijalne svrhe.

Kada je reč o povezanosti između osobina ličnosti i dimenzija vršnjačkog nasilja, rezultati podržavaju Ajzenkovu (Eysenck, 1976 prema Smederevac i Mitrović, 2006; Eysenck, 1977 prema van Dam et al., 2007) tezu o dimenzijama PEN modela kao značajnim prediktorima delinkventnog ponašanja. Iako se delinkvencija ne može izjednačiti sa vršnjačkim nasiljem, izvesne analogije, ovde primetne najpre u strukturi dimenzije rizično ponašanje, postoje. Ekstraverzija se tako javlja kao značajan prediktor dimenzije rizično ponašanje, koja, između ostalog, podrazumeva traženje stimulacije u socijalno neprihvatljivim aktivnostima. Neuroticizam korespondira sa dimenzijom viktimizacija; imajući u vidu da visok skor na ovoj dimenziji ne isključuje mogućnost istovremenog nasilničkog ponašanja potencijalne žrtve, može se pretpostaviti da je veza Neuroticizma sa fenomenom vršnjačkog nasilja složena. Naime, Neuroticizam se može posmatrati kao predisponirajući faktor za ulogu pasivne žrtve; međutim, neki njegovi aspekti- poput hipersenzitivnosti- mogu se shvatiti i kao potencijalni prediktori nasilničkog ponašanja, ili ponašanja žrtve - provokatora. Psihoticizam je, u skladu sa očekivanjima, značajno parcijalno povezan sa dimenzijama koje uključuju kako eksplicitnu agresiju, tako i širok spektar ponašanja povezanih sa nasilništvom.

\section{Zaključak}

Rezultati ovog istraživanja svedoče u prilog teze o kompleksnosti fenomena vršnjačkog nasilja, i njegovoj značajnoj povezanosti sa osobinama ličnosti, vaspitnim stavovima roditelja i polom. Sadržaj ekstrahovanih dimenzija u skladu je sa nalazima ranijih studija (Plut i Popadić, 2007), pri čemu markeri rizičnih ponašanja značajno učestvuju u sadržaju dimenzije koja obuhvata i tendenciju ka gruboj fizičkoj agresiji. To sugeriše da bi fenomen vršnjačkog nasilja trebalo posmatrati u širem kontekstu, i da bi potencijalni programi za prevenciju nasilništva u školama trebalo da, bar u izvesnim aspektima, budu usmereni na identifikaciju i predupređenje rizičnih ponašanja. $\mathrm{S}$ druge strane, rezultati ukazuju na potrebu podrobnijeg razmatranja fenomena viktimizacije. Iako je praktično nepostojanje korelacije između viktimizacije i preostalih dimenzija bilo očekivano, ono ukazuje da zdravorazumsko shvatanje žrtve kao pasivnog objekta nasilja zahteva reviziju. Moguće je da bi uključivanje markera ponaša- 
nja žrtve - provokatora (koji ne podrazumevaju isključivo pasivno reagovanje na agresiju) u upitnik PRONA doprinelo rasvetljavanju ovog fenomena. U vezi $\mathrm{s}$ tim, zanimljiv problem za buduća istraživanja mogla bi biti uloga defanzivne agresije u strukturi nasilničkog ponašanja, bez obzira da li je reč o samoodbrani ili o zaštiti drugih.

Povezanost vršnjačkog nasilja i dimenzija vaspitnih stavova jedna je od tema koje zaslužuju podrobniju razradu. Naime, iako je veza između viktimizacije i rigidnih vaspitnih stavova majke značajna, moglo se očekivati da će indikatori lošijih porodičnih odnosa biti povezani i sa dimenzijama koje se odnose na nasilničko ponašanje. Iako ovakav rezultat upućuje na neophodnost daljeg istraživanja veze porodične klime i vršnjačkog nasilja, moguće je da bi izvesne metodološke modifikacije doprinele jasnijem sagledavanju rezultata. To se pre svega odnosi na dopunu upitničke baterije instrumentima usmerenim na procenu drugih aspekata porodičnih odnosa, ali i na uključivanje roditelja u uzorak ispitanika. Takođe, ovakvi rezultati ukazuju na potrebu da se i roditelji, pored samih učenika, uključe u programe prevencije nasilja.

Iako je ovim istraživanjem obuhvaćen relativno mali uzorak ispitanika uskog uzrasnog raspona, njegovi rezultati već bi sada mogli da posluže kao putokaz za sprovođenje potencijalnih programa prevencije vršnjačkog nasilja. To se u prvom redu odnosi na formiranje baterije upitnika namenjene proceni sklonosti ka vršnjačkom nasilju, u cilju identifikacije potencijalnih nasilnika ili žrtava. Njom bi mogao biti obuhvaćen upitnik PRONA, instrumenti za procenu ličnosti, kao i upitnici namenjeni proceni porodičnog funkcionisanja. Iako su merne karakteristike upitnika PRONA prihvatljive prema konvencionalnom kriterijumu, izvesno je da će ovaj instrument biti modifikovan u cilju poboljšanja njegovih metrijskih svojstava. Eventualna dopuna upitnika PRONA mogla bi podrazumevati markere ponašanja žrtve - provokatora i indikatore rizičnih ponašanja koja nisu obuhvaćena ovom verzijom upitnika.

\section{Reference}

Baldry, A. C. (2003). Bullying in schools and exposure to domestic violence. Child Abuse \& Neglect, 27, 713-732.

Barrett, P. (1999). Rejoinder to: The Eysenckian personality structure: A "Giant Three" or "Big Five" model in Hong Kong? Personality and Individual Differences, 26, 175- 186.

Björkqvist, K., Lagerspetz, K. M. J., \& Kaukiainen, A. (1992). Do girls manipulate and boys fight? Developmental trends in regard to direct and indirect 
aggression. Aggressive Behavior, 18, 117-127.

Fonseca, A. C., \& Yule, W. (1995). Personality and antisocial behavior in children and adolescents: an enquiry into Eysenck's and Gray's theories. Journal of Abnormal Child Psychology, 23, 767 - 781.

Frisen, A., Jonsson, A. K., \& Persson, C. (2007). Adolescents' perception of bullying: Who is the victim? Who is the bully? What can be done to stop bullying? Adolescence, 42, 749 - 761.

Gašić-Pavišić, S. (2004). Mere i programi za prevenciju nasilja u školi. Preuzeto 14 . jula 2008, URL: http://www.dioserbia.nbs.ac.yu.pdf.

Genc, L., i Kodžopeljić, J. (1995). Porodično vaspitanje i dimenzije ličnosti. U Đ. Đurić (Ed.) Ličnost u višekulturnom društvu, (pp. 70 - 81). Novi Sad: Filozofski fakultet, Odsek za psihologiju.

Jankauskiene, R., Kardelis, K., Sukys, S. \& Kardeliene, L. (2008). Associations betwen school bullying and psychosocial factors. Social Behavior and Personality, 36, 145-162.

Kline, P. (2000). The handbook of psychological testing: Second edition. London: Routledge.

Maksimović, J., Raković, D., Jovanović, I., Golubović, M., Božić, J., Smederevac, S., Mitrović, D., i Čolović, P. (2008). Upitnik za procenu vršnjačkog nasilja (PRONA). Nepublikovani materijal. Filozofski fakultet, Univerzitet u Novom Sadu, Novi Sad.

Mitrović, D., Smederevac, S., Grujičić, S., i Čolović, P. (2006). Tipološki pristup rizičnom ponašanju adolescenata. Zbornik Instituta za pedagoška istraživanja, 1, 264-278

Österman, K., Björkqvist, K., Lagerspetz, K. J. M., Kauikainen, A., Landau, S. F., Fraczek, S. F., \& Caprara, G. V. (1998). Cross-cultural evidence of female indirect aggression. Aggressive Behavior, 24,1-8.

Plut, D., i Popadić, D. (2007). Reagovanje dece i odraslih na školsko nasilje. Zbornik Instituta za pedagoška istraživanja, 2, 347- 366.

Salmivalli, C., Lagerspetz, K., Bjorkqvist, K., Osterman, K., \& Kaukiainen, A. (1996). Bullying as a group process: Participant roles in their relations to social status within the group. Aggressive Behavior, 22, 1-15.

Sinobad, S. (2005). Obeležja vršnjačkog nasilja u školama. Preuzeto 15. jula 2008, URL: http://www.uds.org.yu/file/tem050.pdf. 
Smederevac, S., i Mitrović, D. (2006). Ličnost- metodi i modeli. Beograd: Centar za primenjenu psihologiju.

Smith, P. K. \& Brain, P. (2000). Bullying in schools: Lessons from two decades of research. Aggressive Behavior, 26, 1-9.

Van Dam, C., de Bruyn, E. E. J., \& Janssens, M. A. M. J. (2007). Personality, delinquency, and criminal recidivism. Adolescence, 42, 763 - 777. 


\title{
ABSTRACT
}

\section{RELATIONS BETWEEN BULLYING, PERSONALITY TRAITS AND PARENTING PRACTICES}

\author{
Jelena Maksimović, Dušica Raković, Ivana Jovanović, and Petar Čolović
}

The main aims of this research were examination of a latent structure of the PRONA questionnaire, intended to measure proneness to bullying, as well as the examination of the relations between the latent dimensions of the PRONA questionnaire and the dimensions of Eysenck's PEN model, parenting practices, age, and gender. The research was conducted on a sample of 123 participants of both genders, aged 11 - 13. Proneness to bullying was measured by the 42- item PRONA questionnaire, while Junior EPQ (JEPQ) was used to assess the personality traits of Eysenck's model. Parenting practices were measured by the UVS questionnaire, a 49-item measure. Applying a principal component analysis with Promax rotation, three latent dimensions (which accounted for approximately $31 \%$ of variance) were extracted and interpreted as risky behavior, victimisation and psychological harassment. The relations between these dimensions, personality traits, parenting practices, age, and gender were examined by a multivariate analysis of covariance. Factor scores on the Promax dimensions of the PRONA questionnaire were the criteria, while gender was a categorical predictor, and the JEPQ's and UVS' first principal components' factor scores were continuous predictors (covarieties). Psychoticism, Lie scale, and Extraversion significantly partially contributed to the prediction of risky behavior scores. Neuroticism, Lie scale, and the dimension of mother's restrictive parenting style were significant predictors of the victimization, while Psychoticism and gender (boys scoring higher) were significantly partially related to psychological harassment.

Key words: bullying, PEN model, parenting practices 